\title{
Development of Learning Device with Connected Mathematics Characterized through Think Pair Share Model on Multivariate Calculus Class
}

\author{
Mayang Dintarini \\ Mathematics Education Study Program \\ University of Muhammadiyah Malang \\ Malang, Indonesia \\ mayangdintarini@umm.ac.id
}

\begin{abstract}
Students of Mathematics Education Study Program are required to understand not only mathematical concepts but also to understand the relationship between concepts in mathematics, relations of mathematics with daily life and relations of mathematics with other fields of science. It means, Mathematics Education students must have a mathematical connection ability. This study aims to describe development of learning device with connected mathematics characterized through hink pair share model on multivariate calculus class. The subject of this study are fourth students of 3rd grade students of mathematics education study program. The development steps undertaken are: define, design and develop. Learning device (lesson plan and student activity sheet) contains activities that can improve students' mathematical connection ability.
\end{abstract}

Keywords: mathematical connections, Think Pair Share, multivariate calculus class

\section{INTRODUCTION}

Undergraduate program of mathematics education at University of Muhammadiyah Malang currently has applied Higher Education Curriculum which includes National Standard of Higher Education (SN Dikti). In KPT there are four aspects of graduate learning achievement that is attitude, general skill, special skill and knowledge. One of the elaboration of specific skills aspects and knowledge contained in the KPT is 1) applying Islamic values in mathematics education to build Indonesian society as the main community which is globally competitive and 2) mastering the formulation of procedural problem solving in the field of mathematics education. Both of these graduate learning achievements require UMM mathematics students to understand not only mathematical concepts, but also to understand the interrelationship between concepts in mathematics, mathematical relation with daily life and mathematical relation with other fields of science. The relevance of mathematics with other disciplines emphasized in this paper is the relevance of mathematics with Islamic values according to the achievement of graduate learning program S1 Mathematics Education UMM.
Mathematical connection is a person's ability to present relationships between topics in mathematics, mathematical relationships with other disciplines, and the relationship of mathematics to everyday life. This is in line with the nature of mathematics that a mathematics is a systematic and structured science which its concepts are well ordered and interrelate each other. On the other hand, mathematics is also a science that contains symbols, rules, and operation used to solve other scientific problems in the real world. Mathematical connection becomes more important as it supports students to comprehend a concept substantially and assists them to improve their understanding on other disciplines through interrelationship between concepts of mathematics and concepts of other disciplines. [2]

When students can connect mathematical ideas, their understanding is deeper and more lasting. They can see mathematical connections in the rich interplay among mathematical topics, in contexts that relate mathematics to other subjects, and in their own interests and experience. Through instruction that emphasizes the interrelatedness of mathematical ideas, students not only learn mathematics, they also learn about the utility of mathematics [3].

The integral function of two variables is one of the subjects in the course of the Multivariate Calculus. Based on the results of interviews to some students of Mathematics Education Study Program who are taking this lecture, shows that students do not understand use of multivariate calculus in everyday life, and the student have difficulties in connecting the material with the precondition material. This indicates that the need for the development of learning device that can add the students mathematical connections.

Learning device developed include lesson plan and student worksheets with mathematical connections characterized. The learning model that researchers choose to use in lesson plan is Think Pair Share. Think Pair Share is one of the learning models that gives students the opportunity to work individually or in groups. There are three stages in this 
Think Pair Share model, that is think, pair and share. Think, when teacher give students the task, students are given time to think for a moment about the task. Students can try to find answers of the task and find things they may not understand to, then discuss it with their partner. Pair is the stage where students in pairs discuss their opinions about the assigned tasks and sharing of problems they have with the partner and answers to the task. Share is the stage where students present pairing results, and share information with other partners about the task. This is in line with the opinion of Think Pair Share will help the students to think by giving them time to think, then involved with their partner and look the different point of view of the task through their partner. They may be more willing and less apprehensive about sharing with a larger group, and it gives them time to change their response if needed, and reduce the fear of giving the wrong answer and it is encouraging them to participate cooperative, mutual learning between individuals, and ensure that the contribution of each student's work. [4]

Based on the above explanation, the purpose of this study is 1) how the development of learning devices characterized by mathematical connections of learning devices characterized by mathematical connections? and 2) how is the application of learning device characterized by mathematical connection through think pair share model on material integral function of two variables?

\section{METHOD}

This research uses qualitative quantitative approach. This research has two focus, that is development of learning device characterized by mathematical connection and application of the device by using model of TPS in class. To develop learning tools, researchers adapted the 4D Model (define, design, develop, and desiminate) [5]. The steps of device development carried out in this study are described in the chart below.

Fig. 1. The steps of development of learning device

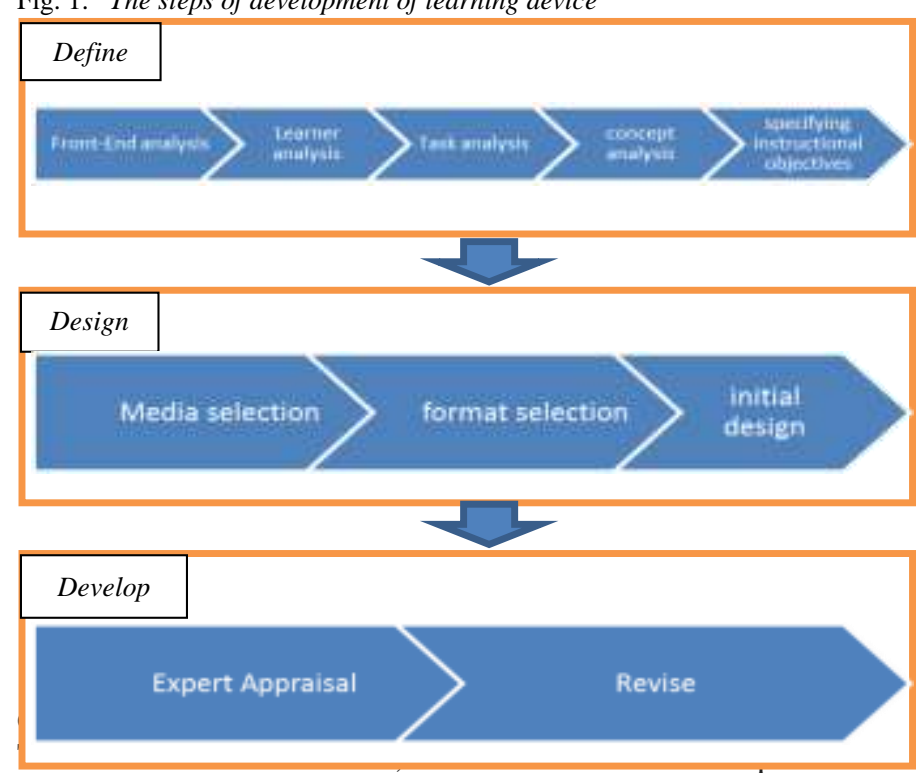

approach, with the research subject is 40 students of University of Muhammadiyah Malang who are taking the course of
Calculus Various and have been taking Differential and Integral Calculus.

The data collection technique used is observation, observation is done by one observer. Observer in charge of recording or writing the invention and activities during the implementation of learning device.

\section{RESULT AND DISCUSSION}

The development of learning devices characterized by mathematical connections through the TPS model on the integral material of two variable functions is described in detail as follows.

\section{A. Define}

In this stage there are 5 activities performed.

a. Front-end analysis, diagnose the initial need to improve the effectiveness of learning. In this study, researchers make a diagnosis of the difficulties of lecturers and students in learning activities and learning needs that need to exist to improve the effectiveness of learning.

b. Learner analysis, analyzing the extent to which the student's learning experience.

c. Task analysis, analysis of tasks that must be given to students to achieve the skills or competencies that have been set.

d. Concept analysis, analyzing concepts that students need to understand in learning.

e. Concept analysis, analyzing concepts that students need to understand in learning.

TABLE I. FINDINGS OF DEFINE STAGE

\begin{tabular}{|l|l|}
\hline \multicolumn{1}{|c|}{ Define Stage } & \multicolumn{1}{c|}{ Findings } \\
Front-end & $\begin{array}{l}\text { The difficulties encountered include } \\
\text { misconceptions among students about the } \\
\text { material being taught, the students have } \\
\text { difficulty in relating the calculus of many } \\
\text { variables with daily life, prerequisite } \\
\text { materials and other disciplines. }\end{array}$ \\
\hline Learner analysis & $\begin{array}{l}\text { Students have experience in the courses of } \\
\text { differential calculus and Integral calculus. }\end{array}$ \\
\hline Task analysis & $\begin{array}{l}\text { The task that must be obtained by the } \\
\text { students is the activity that can connect the } \\
\text { intergral material of two variables with the } \\
\text { integral of one variable, the calculus of } \\
\text { many variables with daily life, and the } \\
\text { calculus of many variables with other } \\
\text { disciplines }\end{array}$ \\
\hline Concept analysis & $\begin{array}{l}\text { The concept that students need to } \\
\text { understand is the concept of integral two } \\
\text { variables. }\end{array}$ \\
\hline $\begin{array}{l}\text { Specifying } \\
\text { instructional } \\
\text { objectives }\end{array}$ & $\begin{array}{l}\text { Through the TPS model, students are able } \\
\text { to have mathematical connection capability } \\
\text { in the integral material of two variables. }\end{array}$ \\
\hline
\end{tabular}

\section{B. Design}

Design's stage divided into four activities, that is:

\section{Media Selection}

The right media according to the researcher is the student worksheet medium. The student worksheet is 
deemed most appropriate for achieving the predetermined learning objectives and in accordance with the material characteristics of the integral functions of the two variables, of which the material is quite abstract. And the understanding of students who are already high enough, which should have reached the abstract stage, so it does not require media that concretize this material.

\section{Format Selection}

In accordance with the purpose of learning, Student Activity Sheets are given to students through Think Pair Share Model. The Think Pair Share model is considered the most appropriate, because in this model, students are given the flexibility to think individually. In this stage of thought it is expected that students find out where their difficulties to be discussed in the pair stage. And get assurance of answers in thap share.

\section{Initial Design}

The researcher stages the conceptual framework and learning tools such as materials, student activity sheets, and tests.

\section{Develop}

1. Expert validation (Expert appraisal), validation of learning devices conducted by one lecturer of Mathematics Education Study Program University of Muhammadiyah Malang to assess the validity of learning devices.

2. Revisions are based on expert validation results. That is there must be a link between mathematics and Islamic Education, because the subject are University of Muhammadiyah Malang. So, the researcher cited some ayah from Qur'an that related to the topic.

3. Developmental testing (implementation), carried out to 40 students of the University of Muhammadiyah Malang who are taking the course of Multivariate Calculus class and have been taking Differential and Integral Calculus class.
The implementation steps as follows.

TABLE II. THE IMPLEMENTATION STEPS

\begin{tabular}{|c|c|c|}
\hline Lecturer's Activities & Stage & $\begin{array}{l}\text { Mathematical } \\
\text { Connection }\end{array}$ \\
\hline $\begin{array}{l}\text { Draw a function graph of two } \\
\text { or more variables }\end{array}$ & $\begin{array}{l}\text { Appercepti } \\
\text { on }\end{array}$ & \\
\hline $\begin{array}{l}\text { Lecturers ask students to } \\
\text { mention the application of } \\
\text { the function of two or more } \\
\text { variables in everyday life }\end{array}$ & Motivation & $\begin{array}{l}\text { 1. Connect the functions of } \\
\text { two variables with daily } \\
\text { life. } \\
\text { 2. Connect the function of } \\
\text { two variables with other } \\
\text { fields of science (religion } \\
\text { and computer) }\end{array}$ \\
\hline $\begin{array}{l}\text { Students work on individual } \\
\text { student worksheets }\end{array}$ & Think & \multirow{3}{*}{$\begin{array}{l}\text { Connecting two variable } \\
\text { functions with other } \\
\text { mathematical concepts } \\
\text { (one variable function) }\end{array}$} \\
\hline $\begin{array}{l}\text { Students discuss the task in } \\
\text { pair }\end{array}$ & Pair & \\
\hline $\begin{array}{l}\text { Some paired students present } \\
\text { the discussion result. }\end{array}$ & Share & \\
\hline $\begin{array}{l}\text { Making a conclusion of } \\
\text { discussion }\end{array}$ & Share & \\
\hline
\end{tabular}

\section{CONCLUSION}

The conclusion of this study is: to develop the learning device the researcher use three steps of 4D model that is, define, design and develop. Define used to analyze the need of learning. Design is the stage to create the learning device. And develop is the stage to asses and revise the learning device.

\section{ACKNOWLEDGMENT}

The preferred spelling of the word "acknowledgment" in America is without an "e" after the "g." Avoid the stilted expression "one of us (R. B. G.) thanks ...". Instead, try "R. B. G. thanks...". Put sponsor acknowledgments in the unnumbered footnote on the first page.

\section{REFERENCES}

[1] Program Studi Pendidikan Matematika UMM, Kurikulum Perguruan Tinggi Program Studi Pendidikan Matematika UMM. Malang, 2017.

[2] H. Hendriana, U. R. Slamet, and U. Sumarmo, "Mathematical Connection Ability And Self-Confidence (An experiment on Junior High School students through Contextual Teaching and learning with Mathematical Manipulative)," Int. J. Educ., vol. 8, no. 1, pp. 1-11, 2014

[3] NCTM, Principle and Standards for School Mathematics. Reston NCTM, 2000

[4] R. Khaleel and A. Hamdan, "The Effect of ( Think - Pair - Share ) Strategy on the Achievement of Third Grade Student in Sciences in the Educational District of Irbid," vol. 8, no. 9, pp. 88-95, 2017.

[5] Thiagarajan et al. (1974). Instructional Development For Training Teacher of Expectional Children. Minnepolis, Minnesota: Leadership Training Institute/ Spesial Education, University of Minnesota. 